\title{
Cryptoccoccal meningitis in post-covid 19 patient in the city of Manaus: Case report
}

DOI: $10.46932 /$ sfjdv3n1-004

Received in: Dec 30st, 2021

Accepted in: Jan 1th, 2022

\section{Thulio Gonçalves da Rocha e Silva}

Veterinary Medicine Undergraduate

Amazonas State Federal Institute of Education, Science and Technology (IFAM), Manaus East Zone Campus (CMZL)

Avenida Cosme Ferreira, ${ }^{\circ}$. 8.045, São José Operário, Manaus/AM

E-mail: thuliorocha15@gmail.com

\section{Tammy Souza dos Santos}

Veterinary Medicine Undergraduate

Amazonas State Federal Institute of Education, Science and Technology (IFAM), Manaus East Zone Campus (CMZL)

Avenida Cosme Ferreira, nº. 8.045, São José Operário, Manaus/AM

E-mail: tammysouza89@gmail.com

\section{Eliane Christine Silva de Souza}

Veterinary Medicine Undergraduate

Amazonas State Federal Institute of Education, Science and Technology (IFAM), Manaus East Zone Campus (CMZL)

Avenida Cosme Ferreira, ${ }^{\circ}$. 8.045, São José Operário, Manaus/AM

E-mail: elianesouza.pmm@gmail.com

\section{Edson Francisco do Espírito Santo}

$\mathrm{PhD}$ in Animal Science from Paulista State University "Júlio de Mesquita Filho

Amazonas State Federal Institute of Education, Science and Technology (IFAM), Manaus East Zone Campus (CMZL)

Avenida Cosme Ferreira, nº 8.045, São José Operário, Manaus/AM

E-mail: edson.santo@ifam.edu.br

\begin{abstract}
Cryptococcosis is a cosmopolitan and opportunistic mycosis, caused mainly by the etiological agent Cryptococcus neoformans, through the inhalation of fungal structures, especially in bird feces. The aim of this study was to report a reported case of cryptococcal meningitis in an immunosuppressed patient due to previous COVID-19 infection in the city of Manaus-AM, as well as to implement health education actions to prevent cryptococcosis in the region of the disease. Information about the case was obtained through access to the database of the Information System for Notifiable Diseases (SINAN), made available by the Center for Control of Zoonoses Dr. Carlos Durand (CCZ), an agency belonging to the Municipal Health Department of Manaus (SEMSA). The case patient, male, presented symptoms such as headache, fever, vomiting, seizures, neck stiffness, petechiae and hemorrhagic suffusions, hearing loss and signs of Kernig and Brudzinski. In a zoosanitary visit to the site of the injury, the presence of pigeon excreta on the walls of the residence was found, and cleaning was carried out without the use of personal protective equipment (PPE's). The contact with the residents evidenced the lack of information about the zoonosis addressed, including the risk of transmission of cryptococcosis by pigeons, facts that make necessary more sanitary actions on zoonoses among the population of Manaus.
\end{abstract}


Keywords: cryptococcosis, infectious diseases, immunodepressed, pigeons, zoonosis.

\section{INTRODUCTION}

Infectious diseases are caused by specific agents or by toxins produced by them, through the transmission of this agent or its toxic product, from an infected person or animal, or from a reservoir to a susceptible host, either directly or indirectly mediated by a vector or environment (BRASIL, 2005). In this context, cryptococcosis, also known as Torulosis, European Blastomycosis or Busse-Buschke disease, is a mycosis of cosmopolitan distribution and opportunistic character, caused by species of Cryptococcus (SORREL; ELLIS, 1997; ORDÓNEZ; CASTÃNEDA, 2001).

The etiological agent of cryptococcosis with the highest incidence is $C$. neoformans, an encapsulated yeast that has a remarkable ability to infect and cause disease in a variety of hosts (CASADEVALL et al., 2000; CHIKAMORI; FUKUSHIMA, 2005). The high prevalence of the yeast in environmental isolates, associated with the rare human-to-human or animal-to-animal transmission, indicates that the infection is acquired through environmental sources of the fungus, mainly through inhalation of its structures, especially in bird feces (GATES et al., 2004; KOMMERS et al., 2005), mainly pigeons (REOLON et al., 2004), where it can remain for more than two years (MARCASSO, 2005).

The factors that induce the pathogenicity of C. neoformans are divided into two groups: one related to the characteristics of the establishment of infection and the ability to survive in the host, and the other related to virulence factors affecting the degree of pathogenicity (REOLON et al., 2004). Infection in humans occurs when the fungus is aerolized and inhaled, presenting from an asymptomatic colonization (situation in which the yeasts remain latent or die, due to control and elimination by the immune system in the lung) (NOLAN et al., 2017), to a primary infection causing pulmonary symptoms, such as isolated or multiple nodular lesions with gelatinous characteristic and masses of subpleural location.

Symptomatic patients may present with fever, cough with mucoid sputum, chest pain and weight loss, pneumonia, and respiratory failure (NADROUS et al., 2003). However, the most commonly diagnosed clinical form is meningoencephalitis, occurring in over $80 \%$ of cases, isolated or associated with pulmonary involvement. This occurs because the yeast has a tropism for the central nervous system, leading to the involvement of the meninges, causing acute, subacute or chronic meningitis, as well as severe and fatal meningoencephalitis, which can even lead to the death of the individual. The most frequent symptoms are headache, fever, cranial neuropathy, altered consciousness, lethargy, memory loss, signs of irritation of the meninges, and coma. For diagnosis, the most indicated method is the investigation of the circulating polysaccharide antigen in serum and CSF by the latex test. The detection of specific antigens of this yeast can also be obtained by the enzyme-linked immunosorbent assay ELISA technique, 
and an auxiliary diagnosis of cryptococcosis in humans can be made by the late-reading intradermal test using cryptococcin (BIVANCO et al., 2006).

Brazilian studies have reported that the casuistry of cryptococcosis by C. neoformans differs according to sex and age, with a higher prevalence in individuals with previous infections, such as those with HIV (DAMBRÓS, 2005; LEAL, 2006); however, in the case of infection by C. gattii, this generally affects patients without evident immunocompromise (BALTAZAR, 2009).

International multicenter studies have shown that the mortality rate of HIV affected patients approached $69 \%$, with most patients who died occurring within the first 30 days of coinfection (MANOSUTHI et al., 2006), with the prevalence of the disease ranging from 2.9 to $13.3 \%$, representing an important cause of mortality in AIDS, despite the establishment of specific treatment (BALTAZAR, 2009).

In December 2019, the New Coronavirus 2019 epidemic began. Its etiologic agent, currently identified as Severe Acute Respiratory Syndrome Coronavirus 2 (SARS-CoV-2), causes a disease called COVID-19 (MOURA et al., 2021). There is evidence that COVID-19 also compromises the nervous system and triggers cutaneous signs and symptoms, which are post-infectious manifestations (LANG et al., 2020; MIECZKOWSKA et al., 2020).

This study aims to report a reported case of cryptococcal meningitis in a patient immunosuppressed by previous infection of COVID-19 in the city of Manaus-AM, as well as to implement health education actions for the prevention of cryptococcosis in the region of the grievance.

\section{CASE REPORT}

The information about the case reported in this paper was obtained from the notification of cryptococcal meningitis in the city of Manaus-AM, through the Information System of Notifiable Diseases (SINAN) and made available by the Zoonosis Control Center Dr. Carlos Durand (CCZ), an agency belonging to the Municipal Health Secretariat of Manaus (SEMSA).

The patient, a brownish male, single, 42-year-old truck driver, was admitted to a public hospital in Manaus on April 20, 2021, presenting symptoms such as headache, fever, vomiting, convulsions, neck stiffness, petechiae and hemorrhagic suffusions, hearing loss, and Kernig and Brudzinski signs, the latter used in the physical examination to detect meningitis. Some of the symptoms reported had started about three days before admission.

The CSF was collected through lumbar puncture, and had a turbid appearance, indicating the occurrence of infectious processes. The analysis of the collected sample confirmed the case of cryptococcal meningitis in the patient, who died of septic shock and cerebral cryptococcosis six days after admission. 
Additional information related to the patient's medical history included preceding COVID-19 infection, requiring hospitalization, that occurred about two months prior to hospitalization due to cryptococcosis. Between hospitalizations, the patient presented with pneumonia, most likely caused by the depression of his immune system and compromise of his respiratory system by COVID-19.

During a zoosanitary visit to the site of the grievance, the presence of pigeons and their excrement was verified on the eaves of the roof and on the wall of the neighboring residence, as shown in Figure 1, and due to the proximity between the houses, they ended up falling into the patient's yard, who cleaned the place daily without the use of Personal Protective Equipment (PPE). At the time of the visit, family members who lived with the patient reported no symptoms consistent with meningitis.

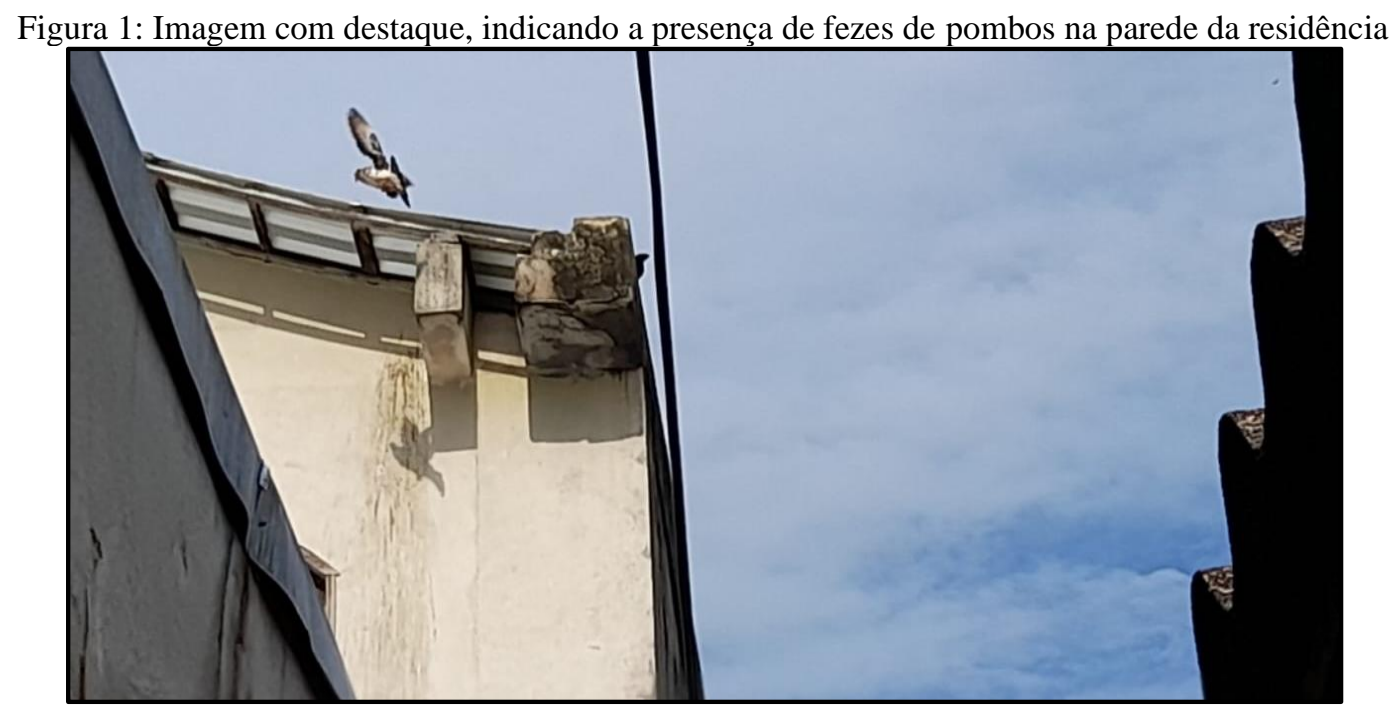

Fonte: Rocha e Silva, 2021.

\section{DISCUSSION}

The epidemiology of cryptococcosis has been described in different studies, and according to Dambrós (2005) and Leal (2006), if the disease is caused by C. neoformans, there is a higher prevalence in males, aged 30 to 39 years old, and HIV carriers. Regarding the latter, it was found that some symptoms remain after acute infection control (FRASER, 2020). According to Moura et al. (2021), investigations are still limited, but the data already surveyed allow us to highlight sequelae in the respiratory and cardiac systems.

The reports of the correlation between COVID-19 and cryptococcosis are still scarce, although the occurrence of cutaneous and neurological forms of cryptococcosis in an immunocompromised patient who died during the epidemic outbreak of SARS-COV-2 due to respiratory failure has already been reported, but the most intriguing factor is that despite not manifesting the cutaneous and neurological signs, the patient still presented the cryptococcal antigen (PASSERINI et al, 2020). 
In the case of the patient of the present report, due to the previous involvement of the respiratory system by COVID-19, which was still recovering when infected with the fungus causing cryptococcosis, there was a difficulty in correlating the symptoms with the fungal disease, since pulmonary infection in some cases can be asymptomatic or even confused with tuberculosis, due to the fact that affected individuals present cough, dyspnea, weight loss, chest pain and purulent effusion in the pleura reaching lung failure (ALMEIDA, 2012). After the involvement of the lungs, the infectious agent usually spreads by hematogenous or even lymphatic means to other areas of the body, with predilection for the central nervous system, causing meningitis in the patient (DA SILVA, GAGLIANI, 2014).

Taking into consideration research on the neurological manifestations arising from COVID-19, according to Liu et al. (2020) it is important to perform a broad pathogen screening for patients with COVID-19, who present symptoms related to encephalitis or meningitis.

Regarding the Health Education actions developed, these were carried out in the location where the grievance occurred and included the delivery of leaflets about the importance of pigeon control (Figure 2). This material contained information about the measures used to eliminate shelter, food and water sources, as well as the removal of excreta from these animals and cleaning of the environment using PPE and disinfectant solutions appropriately, aiming to guide the residents of the region about the risk of contamination, prevention and control of meningitis caused by $C$. neoformans present in pigeon droppings.

Figura 2: Fôlder utilizado na ação de educação em saúde.
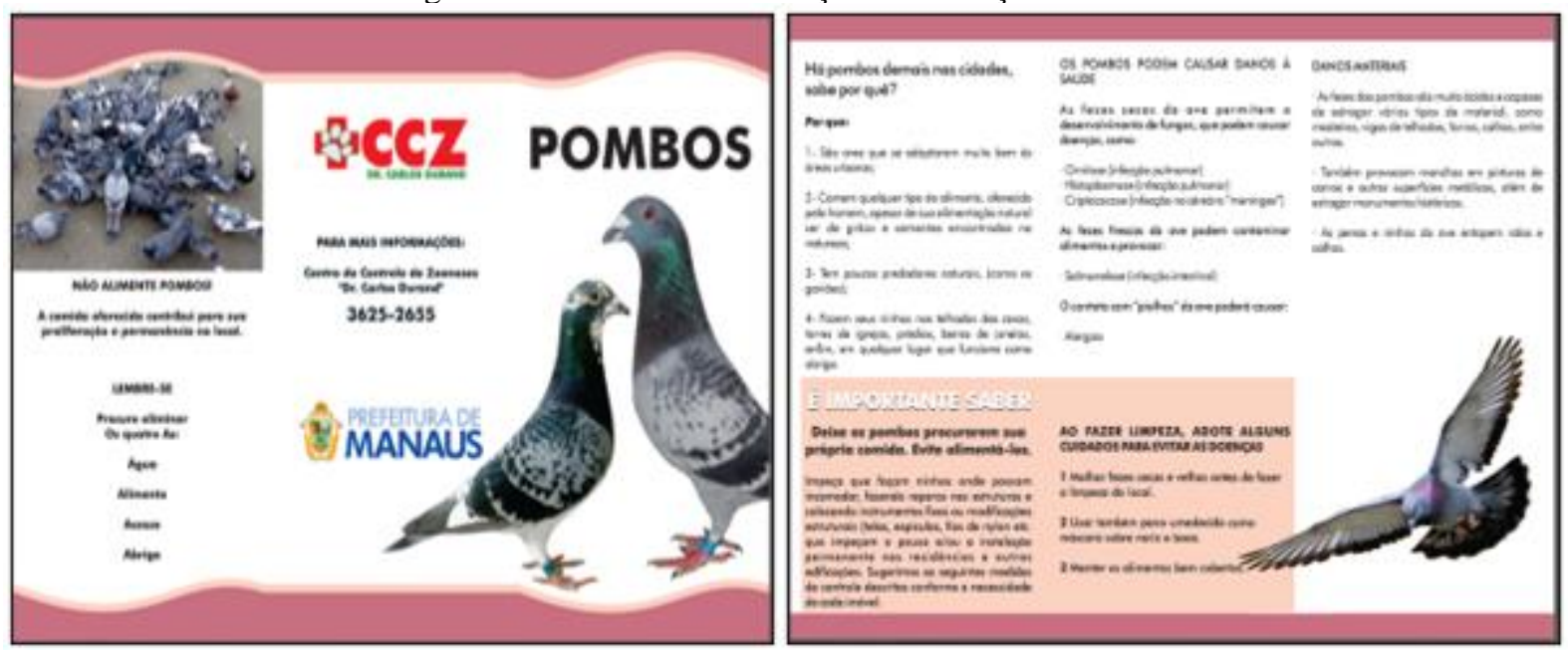

Fonte: CCZ Dr. Carlos Durand.

The fact that the family members who lived with the patient did not show symptoms compatible with meningitis does not mean that they did not get infected, but it confirms that this disease, when of fungal origin, is not transmissible from man to man. According to Ooi et al. (1978), with the exception of two cases of transmission via transplanted organs, there is no known human-to-human transmission, but 
through environmental contamination, and mainly through inhalation of $C$. neoformans spores contained in pigeon droppings.

\section{CONCLUSION}

The devastating effects of the COVID-19 pandemic, even with vaccination, social isolation, and hygiene measures, still cause great concern, especially for those people who had more serious respiratory system involvement and still survived. This fact becomes even more important when considering the high concentration of pigeons in urban areas in the city of Manaus. However, when dealing with immunosuppressed patients, the possibility of contamination with Cryptococcus neoformans cannot be overlooked.

Additionally, the contact with the residents during the health education activities mentioned in this report evidenced the lack of information about the zoonosis addressed. Thus, more health actions on zoonoses are necessary among the population of Manaus.

\section{ACKNOWLEDGEMENTS}

We thank the Zoonosis Control Center Dr. Carlos Durand, the School of Public Health - ESAP, and the Municipal Health Secretariat - SEMSA, for making it possible to obtain data and publish information pertinent to the report of this case so relevant to public health. 


\section{REFERENCES}

Almeida, J. C. D. (2012). Perfil clínico-Epidemiológico da criptococose em pacientes HIV positivos atendidos em uma unidade de referência em Belém do Pará. 77f. Dissertação de Mestrado. Universidade Federal do Pará.

Baltazar, L. M. (2009). Fatores de virulência e suscetibilidade a drogas antifúngicas de cepas clínicas e ambientais de Cryptococcus spp. 135f. Dissertação de Mestrado. Universidade Federal do Espírito Santo, Espírito Santo.

Bivanco, F. C., Machado, C. D. S., Martins E. L. (2006). Criptococose cutânea. Arquivos Médicos do $A B C, 31$ (2), 102-109.

Brasil. Ministério da Saúde. Secretaria de Vigilância em Saúde Guia de vigilância epidemiológica. 6.ed. - Brasília, 2005. Disponível em: <https://bvsms.saude.gov.br/bvs/publicacoes/Guia_Vig_Epid_novo2.pdf>. Acesso em: 15 Jun. 2021.

Casadevall, A., Rosas, A., Nosanchuk, J. D. (2000). Melanin and virulence in Cryptococcus neoformans. Current opinion in microbiology, 3 (4), 354-358.

Chikamori, M., Fukushima, K. (2005). A new hexose transporter from Cryptococcus neoformans: Molecular cloning and structural and functional characterization. Fungal genetics and biology, 42 (7), 646-655.

Da Silva, M. A. P., Gagliani, L. H. (2014). Diagnóstico e prevalência da meningite criptococócica em pacientes portadores da Síndrome da Imunodeficiênca Adquirida-SIDA. UNILUS Ensino e Pesquisa, 11 (22), 23-44.

Dambrós, B. P. (2005). Variabilidade genética de Cryptococcus neoformans isolado de pacientes HIV positivos atendidos no Hospital Nereu Ramos de Florianópolis, Santa Catarina. 88f. Dissertação de Mestrado. Universidade Federal de Santa Catarina, Santa Catarina.

Fraser, E. (2020). Long term respiratory complications of covid-19. British Medical Journal. Disponível em: < https://doi.org/10.1136/bmj.m3001>. Acesso em: 05 de out., 2021.

Gates, M. A., Thorkildson, P., Kozel, T. R. (2004). Arquitetura molecular da cápsula de Cryptococcus neoformans. Microbiologia molecular, 52 (1), 13-24.

Kommers, G. D., Souza, T. M. D., Souto, M. D. A. M., La Corte, F. D. D., Barros, C. S. L. D. (2005). Criptococose pulmonar granulomatosa em um equino. Ciência Rural, 35 (4), 938-940.

Lang, M., Buch, K., Li, M. D., Mehan, W. A., Lang, A. L., Leslie-Mazwi, T. M., Rincon, S. P. (2020). Leukoencephalopathy associated with severe COVID-19 infection: sequela of hypoxemia? American Journal of Neuroradiology, 41 (9), 1641-1645.

Leal, A. L. (2006). Diferenciação das espécies Cryptococcus neoformans e Cryptococcus gattii utilizando a metodologia PCR multiplex e determinação do perfil epidemiológico de pacientes com meningite criptocócica. 100f. Dissertação de Mestrado. Universidade Federal do Rio Grande do Sul, Rio Grande do Sul.

Liu, K., Pan, M., Xiao, Z., Xu, X. (2020). Manifestações neurológicas da pandemia de coronavírus (SARS-CoV-2) 2019-2020. Jornal de Neurologia, Neurocirurgia e Psiquiatria, 91 (6), 669-670. 
Manosuthi, W., Sungkanuparph, S., Thongyen, S., Chumpathat, N., Eampokalap, B., Thawornwan, U., Foongladda, S. (2006). Antifungal Susceptibilities of Cryptococcus Neoformans cerebrospinal Fluid Isolates and Clinical Outcomes of Cryptococcal Meningitis in HIV-Infected Patients with/without Fluconazole Prophylaxis. Journal of the Medical Association of Thailand, 89 (6), 795-802.

Marcasso, R. A. (2005). Criptococose no sistema nervoso de cães: relato de três casos. Semina Ciências Agrárias, Londrina, 26 (2), 229-238.

Mieczkowska, K., Deutsch, A., Borok, J., Guzman, A. K., Fruchter, R., Patel, P., Wind, O., McLellan, B. N., Mann, R. E., Halverstam, C. P. (2020). Telogen effluvium: a sequela of COVID-19. International journal of dermatology, 60 (1), 122-124.

Moura, D. L., Dias, A., Farinha, P. M., Farinha, J. M., Robalo-Cordeiro, C. (2021). Sequelas da COVID19: evidência atual. Rev. Medicina Desportiva , 12 (3), 8-11. Disponível em: <https://doi.org/10.23911/COVID-19_sequelas_2021_mai >. Acesso em: 05 de nov. 2021.

Nadrous, H. F., Antonios, V. S., Terrell, C. L., Ryu, J. H. (2003). Pulmonary cryptococcosis in nonimmunocompromised patients. Chest Journal, 124 (6), 2143-2147.

Nolan, S. J., Fu, M. S., Coppens I., Casadevall, A. (2017). Lipids Affect the Cryptococcus neoformans Macrophage Interaction and Promova Nonlytic Exocytosis. Infection and Immunity Journal, 85 (12). Disponível em: <https://doi.org/10.1128/IAI.00564-17>. Acesso em: 08 de jul, 2021.

Ooi, B., Chen, B. T. M., Lim, C. H., Khoon, O. T., Chan, K.T. (1978). Survival of a patient transpalantyed with a kidney infected with Cryptococcus neoformans. Transplantation, 11 (4), 428-429.

Ordóñez, N., Castañeda, E. (2001). Varietes and serotypes of Cryptococcus neoformans clinical isolates in Colombia. Revista Iberoamericana de Micologia, 18 (3), 128-130.

Passerini, M., Terzi, R., Piscaglia, M., Passerini, S., Piconi, S. (2020). Disseminated Cryptococcosis in a Patient With Metastatic Prostate Cancer Who Died in the Coronavirus Disease 2019 (COVID-19) Outbreak. Cureus Journal of Medical Science, 12 (5), 1-8.

Reolon, A., Perez, L. R. R., Mezzari, A. (2004). Prevalência de Cryptococcus neoformans nos pombos urbanos da cidade de Porto Alegre. Jornal Brasileiro de Patologia e Medicina Laboratorial, 40 (5), 293298.

Sorrell, T. C., Ellis, D. H. (1997). Ecology of Cryptococcus neoformans. Revista Iberoamericana de Micología, 14 (2), 42-43. 